\title{
Bitki Çaylarında Mikrobiyal Kalite ve Mikotoksin Varlığı
}

\author{
Nuray $\mathrm{CAN}^{1}$, Serap DURAKLI VELİĞLU ${ }^{2 *}$ \\ ${ }^{1}$ İstanbul Aydın Üniversitesi, Anadolu Bil Meslek Yüksekokulu, Gıda Teknolojisi Programı, \\ İstanbul, Türkiye \\ ${ }^{2}$ Tekirdağ Namık Kemal Üniversitesi, Ziraat Fakültesi, Gıda Mühendisliği Bölümü, Tekirdağ, \\ Türkiye
}

Geliş / Received: 06/04/2018, Kabul / Accepted: 01/09/2018

\begin{abstract}
$\ddot{O} z$
Bitki çayları, Camellia sinensis dışındaki bitkisel materyalden elde edilmekte olup hem hoşa giden tatları nedeniyle hem de sağlığı korumak ve çeşitli rahatsızlıkları gidermek gibi amaçlarla eski zamanlardan beri kullanılmaktadır. Bununla birlikte, bu ürünlerin hasat öncesinde ve hasat sonrası üretim aşamalarında kontaminasyona uğrayabildiği bilinmektedir. Bu kontaminantlar arasında patojen bakteriler ve mikotoksijenik küfler önemli bir yer tutmaktadır. Bitki çaylarında uygun şartlarda gelişen mikotoksijenik küfler, insan sağllğı üzerinde olumsuz etkileri bulunan mikotoksinleri oluşturabilmektedir. Bu derlemede çay yapımında kullanılan bitkisel materyallerin mikrobiyal kalitesi ve bu ürünlerdeki mikotoksinlerin varlığı üzerine yapılmış çalışmalara yer verilmiştir.
\end{abstract}

Anahtar Kelimeler: Bitki Çayı, Mikotoksinler, Mikrobiyal Kalite

\section{Microbial Quality and Presence of Mycotoxins in Herbal Teas}

\begin{abstract}
Herbal teas are derived from herbal materials other than Camellia sinensis and have been used since ancient times for their pleasurable tastes and for the purpose of maintaining health and relieving various ailments. However, it is known that these crops can undergo contamination prior to harvest and at post-harvest stage of production. Among these contaminants, pathogenic bacteria and mycotoxigenic molds are important. Mycotoxigenic molds that grow under suitable conditions in herbal teas can produce mycotoxins with adverse effects on human health. This review includes the studies that focused on the microbial quality of herbal materials used in tea making and presence of mycotoxins in these products.
\end{abstract}

Keywords: Herbal Tea, Microbial Quality, Mycotoxins

\section{Giriş}

Bitkiler yüzyıllardır beslenme, sağglığı koruma ve çeşitli hastalıkları tedavi etme başta olmak üzere farklı amaçlarla insanlar tarafından kullanılagelmiştir. Günümüzde gıda, sağlık, kozmetik ve parfümeri gibi sektörlerde geniş kullanım alanı bulunan tıbbi ve aromatik bitkiler, son yıllarda dünya pazarlarında yüksek ticari hacme sahip oluşları ile dikkat çekmektedir. Yakın geçmişte uluslararası pazarda tıbbi bitkilere olan talepte iki kat artış olduğu, Dünya Sağlık Örgütü tahminlerine göre, şu an yıllık 14 milyar dolar olan talebin
2050 yılına kadar 5 trilyon dolar olacağı ifade edilmektedir (Bayramoğlu vd., 2009; Faydaoğlu ve Sürücüoğlu, 2011; Sezik, 2011; Tripathy vd., 2015). Asırlardır sağlığa faydalı bileşenlerin en önemli kaynağı olan tıbbi bitkiler, Dünya genelinde geleneksel tıp sistemleri ile entegre halde kullanılmaktadır. Geleneksel tıp sistemlerinde yararlanılan bitkisel ürünlerin büyük bir kısmı çay formunda tüketilmektedir (Vidovic vd., 2013). Bu türden bitkisel ürünlere atfedilen "doğal" ifadesinin zararsız anlamı taşıdığına ilişkin yerleşen yaygın kanaat sebebiyle gelişmiş ülkelerde de kullanımlarının giderek 
arttığı belirtilmektedir (Kosalec vd., 2009). Dünyada olduğu gibi ülkemizde de bitki çayları yaygın olarak kullanılmaktadır. Ülkemizde çay tüketim alışkanlıklarının değerlendirilmesi amacıyla gerçekleştirilen bir araştırmada, bitki çayı tükettiğini belirten katılımcıların bir kısmının bitki çaylarını aktarlardan aldıkları, büyük çoğunluğunun ise marketlerden hazır poşet çay olarak aldığı ortaya konmuştur. Katılımcılar tarafından poşet bitki çaylarını tüketme nedenleri; demlemesinin pratik olması, çeşit sayısının fazla olması, sağlıklı olduğunun düşünülmesi, tat ve aromasının sevilmesi, çeşitli rahatsızlıklara iyi gelmesi ve doğal olduğunun düşünülmesi olarak ifade edilmiştir. Poşet bitki çayı tüketenlerin en yüksek oranda 1hlamuru tercih ettiği, onu sırasıyla adaçayı ve kuşburnunun izlediği bildirilmiştir (Ulusoy ve Şeker, 2013). Bitki çaylarının, tüketiciler tarafından, "doğal", "zararsız" ve/veya "sağlığa faydalı" olarak kabul edilmesine rağmen, yapılan çalışmalar, sıklıkla tıbbi amaçlarla kullanılan bitki çaylarının çeşitli kaynaklar vasitasıyla mikroorganizmalar, mikotoksinler, pestisitler, ağır metaller gibi bazı kimyasal ve biyolojik tehlikeleri barındıran birer araç haline gelebildiğini göstermektedir (Scolari vd., 2001; Chan, 2003; Tripathy vd., 2015). Bitki çaylarının önde gelen kontaminasyon kaynakları arasında yer alan mikroorganizmalar, yaygın bir şekilde hem hasat öncesi hem de hasat, kurutma, sınıflandırma, ögütme, işleme, ambalajlama, depolama gibi üretim aşamaları sırasında bitki çaylarına bulaşabilmektedir. Literatürde bu ürünlerin çeşitli mikroorganizmaları barındırabildiğini, bunlar içerisinde patojen mikroorganizmaların ve mikotoksijenik küflerin yer alabildiğini gösteren çalışmalara rastlanmaktadır (Scolari vd., 2001; Stevic vd., 2012). Bitki çaylarında yaygın olarak bulunabilen mikroorganizmaların içinde mikotoksijenik küflerin yer alması, bu ürünlerin mikotoksinler açısından da riskli ürünler olmasına sebep olmaktadır. Çünkü uygun koşullarda işlenmemiş ham materyalde çoğalan küflerin, ürünün bozulmasına neden olmasının yanında, insan sağlığı üzerinde olumsuz etkileri olan mikotoksinleri de oluşturabildikleri bilinmektedir (Sabuncuoğlu vd., 2008; Erginkaya ve Kabak, 2010). Mikotoksin ifadesi Yunanca mantar anlamına gelen "mykes" ve Latince zehir anlamına gelen "toxicum" kelimelerinden türetilmiştir (Aiko ve Mehta, 2015). Mikotoksinleri, ağız, solunum ya da deriden absorbsiyon yoluyla vücuda alındığında insan ve hayvanlarda hastalık ve ölüme sebebiyet verebilen fungal metabolitler olarak tanımlamak mümkündür (Ashiq vd., 2014). Metabolit kavramı, metabolizma reaksiyonlarında oluşan maddeler için kullanılmakta olup sekonder metabolitler, üretildikleri organizmanın büyümesi için gerekli olmayan ve sadece sinırlı taksonomik gruplarda bulunan bileşikler olarak tanımlanmaktadır. Mikotoksinler, küflerin büyümesi ve gelişimi üzerinde hiçbir biyokimyasal önemi olmayan sekonder metabolitlerdir (Bentley, 1997; Hussein ve Brasel, 2001; Marin vd., 2013). Günümüzde yaklaşık 400 kadar mikotoksin tanımlanmış olup, mikotoksin üreten küf sayısının 350'yi bulduğu bilinmektedir (Tunail, 2000; Ashiq vd., 2014). Aspergillus, Fusarium, Penicillium, Alternaria ve Claviceps cinslerine ait türler, mikotoksin üretme yeteneğine sahip başlıca küflerdir (Huwig vd., 2001; Adams ve Moss, 2007; Do vd., 2015). Bir küf türü birden fazla sayıda mikotoksin üretebilmekte, aynı zamanda bir mikotoksin farklı küf türleri tarafından sentezlenebilmektedir (Tunail, 2000). En s1k karşılaşılan mikotoksinler arasında aflatoksin, fumonisin, okratoksin, patulin, trikotesen ve zearalenon yer almaktadır (Huwig vd., 2001; Aiko ve Mehta, 2015). Mikotoksinlerin doğrudan veya dolaylı olarak tüketimi sonucu insan ve hayvanlar üzerinde meydana getirdiği toksik etkiler "mikotoksikozis" olarak tanımlanmakta olup, bu etkinin şiddeti mikotoksinin toksisitesine, organizmanın mikotoksine maruz kalma derecesine, yaşına, 
beslenme durumuna ve maruz kalınan diğer kimyasallarla olası sinerjistik etkileşime bağlı olmaktadir (Peraica vd., 1999). İnsanlar tarafından, mikotoksin kalıntı ve metabolitlerini içeren bitkisel ve hayvansal gıdaların tüketilmesi yoluyla vücuda alınabilen mikotoksinler, karaciğer ve böbrek fonksiyonlarında bozulmaya yol açabilmekte, nörotoksik etki gösterebilmektedir. Bazı mikotoksinler, protein sentezine müdahale edebilmekte, cilt hassasiyeti veya nekrozdan aşırı immün yetmezliğe kadar değişen etkilere neden olabilmektedir. Bazı mikotoksinler ise teratojenik ve/veya kanserojen olabilmektedir (Hayes vd., 1974; Wogan vd., 1974; Visconti vd., 1991; Belmadani vd., 1998; Sweeney ve Dobson, 1998). Örneğin en yaygın bulunan mikotoksinler arasında yer alan aflatoksinler, International Agency for Research on Cancer (IARC) - (Uluslararası Kanser Araştırma Ajans1) tarafindan "Grup 1: İnsan için Kanserojen” olarak (IARC, 2012), okratoksin A (OTA) ve fumonisin $\mathrm{B}_{1}\left(\mathrm{FB}_{1}\right)$ ise Grup 2B: "İnsanda Kanser Oluşturması Mümkün" (IARC, 1993; 2002) olarak sınıflandırılmıştır. Ülkemizde mikotoksinlerin toksik etkileri üzerine yapılmış çeşitli çalışmalar bulunmaktadır. Aksoy vd. (2008), moniliformin mikotoksininin, insan lenfositlerindeki genotoksisitesini araştırmış ve k1sa süreli muamelelerde in vitro genotoksik etkili bir ajan olduğunu tespit etmiştir. Benzer şekilde Çelik vd. (2009) de, moniliforminle 48 saat süreyle muamele edilen lenfositlerde, kromozomal anormallik testinde kontrole göre anlamlı artışlar gözlemlemiş ve elde ettiği bulguların, moniliforminin insan hücrelerinde kültürde sitogenetik etki gösterebileceğinin kanıtı olduğunu bildirmiştir. Gürbüzel vd. (2010) tarafından yapılan bir çalışmada ise paxilline, genotoksik etki açısından incelenmiş ve $2 \mu \mathrm{M}$ ve daha yüksek konsantrasyonlarda genotosik etkili olduğu bildirilmiştir. Lenfosit kültürlerinin farklı dozlarda patulin ile muamele edildiği bir çalışmada, Dönmez Altuntaş vd. (2013), elde edilen sonuçların yüksek konsantrasyonlarda patulinin kültürlenmiş insan lenfositlerinde genotoksik, sitotoksik ve sitostatik olduğunu gösterdiğini ortaya koymuştur. Aflatoksin $\mathrm{B}_{1}\left(\mathrm{AFB}_{1}\right)^{\prime}$ 'in zebra balığ embriyolarının gelişimi üzerine olan teratojenik etkilerinin araştırıldığı bir çalışmada, artan konsantrasyonlarda $\mathrm{AFB}_{1}$ uygulanan balık embriyolarında, gelişim geriliği, vertebra anormalliği, kardiak ödemi, çeşitli vücut kısımlarının oluşmaması gibi anormallikler gözlenmiş, $\mathrm{AFB}_{1}$ 'e maruz kalma süresi ve $\mathrm{AFB}_{1}$ konsantrasyonu arttıkça bu anormalliklerin görülme sıklı̆̆ının ve ölümlerin arttığı belirtilmiştir (Şişman ve Yıldırım, 2007). Döllenmiş tavuk yumurtalarında $\mathrm{AFB}_{1}$ 'in farklı oranlarda mortaliteye neden olduğu ve embriyotoksik etkilerinin bulunduğu gösterilmiştir (Çelik vd., 2000; Durmuş vd., 2005). Yumurtaya değişik miktarlarda verilen $\mathrm{AFB}_{1}$ 'in civcivlerin çıkış ağırlıklarına etkisinin incelendiği bir çalışmada Aydın vd. (2005), $\mathrm{AFB}_{1}$ verilen grupların civciv çıkış ağırlıklarında ve rölatif civciv ağırlıklarında doza bağımlı olarak önemli düşüşler, mortalitelerinde ise belirgin artışlar gözlemlendiğini bildirmiştir. Öznurlu vd. (2012) tarafindan, in ovo uygulanan $\mathrm{AFB}_{1}$ 'in tibial büyüme plağının embriyonik gelişimini olumsuz yönde etkilediği ve bu piliçlerin büyüme sırasında iskelet bozukluklarına daha duyarlı olabileceği tespit edilmiştir. Bağışıklık sistemi üzerine mikotoksinlerin etkilerinin incelendiği çalışmalar da bulunmakta olup, döllenmiş yumurtalara uygulanan $\mathrm{AFB}_{1}$ 'in hücresel ve humoral bağışıklıkta, özellikle anneden gelen antikorların embriyoya aktarılmasında azalmaya neden olduğu saptanmıştır (Sur vd., 2011). Oğuz vd. (2003), yemlerine 50-100 ppb aflatoksin katılan piliçlerde humoral bağışıklığın gelişimini enfeksiyöz bronşit ve yalancı veba hastalığına karşı incelemiş ve aflatoksin uygulamasının immunotoksik etkilere yol açtığını göstermiştir. Aflatoksinlerin insanlarda hepatoselüler karsinoma gelişimi için bir risk faktörü 
olduğunu belirten Aydın vd. (2015), karaciğer kanseri ve siroz olan/olmayan hepatit B hastalarının serum $\left(\mathrm{AFB}_{1}\right)$, aflatoksin $\mathrm{B}_{2}$ $\left(\mathrm{AFB}_{2}\right)$, aflatoksin $\mathrm{G}_{1}\left(\mathrm{AFG}_{1}\right)$ ve aflatoksin $\mathrm{G}_{2}$ $\left(\mathrm{AFG}_{2}\right)$ konsantrasyonlarını belirlemek amacıyla gerçekleştirdiği bir çalışmada, karaciğer kanseri/siroz olmayan hastalardaki ortalama $\mathrm{AFB}_{1}$ ve toplam aflatoksin düzeylerinin, sağlıklı kontrol grubuna göre anlamlı derecede yüksek olduğunu bildirmiştir. Ayrıca kronik hepatit B ve karaciğer kanseri olan hastalardaki ortalama $\mathrm{AFB}_{1}$ ve toplam aflatoksin düzeylerinin de, sirozlu veya sirozu olmayan hepatit B hastalarına göre anlamlı derecede yüksek bulunduğunu bildirerek bu sonuçların, aflatoksinlere maruz kalan kronik hepatit B hastalarının, hepatoselüler karsinoma gelişimi için yüksek risk altında olduğunu düşündürdüğünü vurgulamıştır. Sağlığa zararlı maddeler içerisinde önemli bir yer tutan mikotoksinlerin, bitki çaylarında bulunabildiğini gösteren bazı çalışmalar mevcuttur. (Halt, 1998; Martins vd., 2001a; Santos vd., 2009). Bu nedenlerle, bitki çaylarının gıda güvenliği açısından değerlendirilmesinde, mikrobiyal kalitesi ve mikotoksin içeriğinin önemi büyüktür.

\section{Materyal ve Metot}

$\mathrm{Bu}$ çalışmada geleneksel olarak çay yapımında kullanılan bitkisel materyallerin mikrobiyal kalitesi ve bu ürünlerde mikotoksin varlığı konusunda yapılan ulusal ve uluslararası bilimsel çalışmalar derlenmiştir.

\section{Bulgular}

\subsection{Bitki Çayları}

Günümüzde sağlık üzerine faydalı etkilerinin bulunması ve hoşa giden tatları sayesinde siyah çay, kahve gibi içeceklere bir alternatif olan ve yaygın şekilde tüketilen bitki çayları, çay bitkisi (Camellia sinensis) dışındaki herhangi bir tıbbi veya aromatik bitkiden hazırlanan çaylar olarak tanımlanabilmektedir (Sezik, 2011; Zegarac vd., 2013). European Pharmacopoeia (Avrupa Farmakopesi) tarafindan yapılan bir başka tanım ise, "ağızdan alıma yönelik olarak kullanılmadan hemen önce bir veya daha fazla bitkisel drogun infüzyon, dekoksiyon ya da maserasyonu yoluyla hazırlanan sulu preparatlardır” şeklindedir (Anonim, 2005). Özellikle son y1llarda, insan beslenmesinde fenolik bileşiklerin ana kaynaklarından biri haline gelen bitki çaylarına olan ilginin artmasında, içerdiği bu bileşiklerin antioksidan aktiviteye sahip olduğunun gösterilmesi etkili olmuştur (Atoui vd., 2005; Ivanova vd., 2005). Çeşitli kronik ve akut hastalıkların tedavisine yönelik olarak tüketilebilen bitki çayları, rahatlıkla temin edilebilmesi, hazırlanmasının kolay olması, çoğunlukla önemli yan etki göstermemesi, ucuz olması, yararlı bileşenlerce zengin olması gibi sebeplerle bir hekime danışmaksızın yaşlılar ve zayıf bünyeli hastalar tarafindan da tercih edilmektedir (Tschiggerl ve Bucar, 2012). Soğuk algınlığı, kabızlık, diyare, hazımsızlık, uykusuzluk ve yorgunluk gibi çeşitli şikayetleri gidermek amacıyla yaygın olarak tüketilen bitki çaylarının, hazırlandığı bitkinin tohum, çiçek, yaprak, gövde, kök ya da bu kısımların tümünden kaynaklanabilen etkisi türe, yetiştikleri bölgeye, hasat zamanına, kurutma yöntemine ve depolama koşullarına bağlı olarak değişebilmektedir (Megahee, 1995; Kökdil, 2002; Chen ve Mujumdar, 2006). Ülkemizde 50-60 civarında bitkinin çay formunda tüketildiği ifade edilmektedir (Sezik, 2004). Binlerce bitkiden çay şeklinde yararlanmak mümkün olmakla birlikte, bir bitkinin çay şeklinde tüketilmesini etkileyen başlıca faktörleri, ülke kültürü, kişisel bilgi birikimi ile bölgedeki bitki çeşitliliği olarak saymak mümkündür (Akgül ve Ünver, 2001). 


\subsection{Bitki Çaylarında Mikrobiyal Kalite}

Büyüyen küresel pazarı ve gittikçe artan kullanımları göz önüne alındığında, halk sağlığına yönelik bir tehlike yaratmaması için, tıbbi bitkilerin kalitesinin ve güvenilirliğinin üzerinde önemle durulması gerekmektedir. Çünkü bu türden ürünlerin, yetişme ve üretim aşamalarına bağlı olarak mikroorganizmalar, toksinler, toksik metaller, pestisit kalıntıları gibi çeşitli bulaşanlara maruz kalabildiği bilinmektedir (Kosalec vd., 2009). Çay yapımında kullanılan bitkisel materyalin mikroorganizmalar ile kontamine olması, toprak, su, gübre, lağım suları, hayvan atık ve artıkları vasıtası ile hasat öncesi olabildiği gibi, hasat, kurutma, sınıflandırma, ögütme, işleme, ambalajlama, depolama gibi üretim aşamaları sırasında da gerçekleşebilmektedir (Özyaral vd., 1994; Heperkan, 2006). Doğadan toplanan ve kültürü yapılan bitkisel materyaller arasında biyolojik kontaminasyonu karşılaştırmaya yönelik yeterli veri bulunmamasına rağmen, kültürü yapılan bitkisel materyalin daha çok hasat sonrasındaki işleme basamaklarında kontamine olduğu düşünülmektedir (Kosalec vd., 2009). Yapılan çalışmalarla, çay yapımında kullanılan bitkilerin yüksek düzeyde toplam bakteri (Wilson vd., 2004; Tournas ve Katsoudas, 2008; Vitullo vd., 2011) ve küf (Halt, 1998; Kolb, 1999; Tournas ve Katsoudas, 2008; Khattak, 2012; Omogbai ve Ikenebomeh, 2013) barındırabildiği, ayrıca koliform grubu bakterilerin (Legnani vd., 2001; Abou Donia, 2008) yanı s1ra, Bacillus cereus, Clostridium perfringens ile bunların sporları ve Salmonella spp. (Martins vd., 2001b; Kaya, 2006; Vitullo vd., 2011) ile kontamine oldukları bildirilmektedir. Bitki çaylarının tüketimi sırasındaki mikrobiyal yükünün, bitkisel materyalin mikrobiyal yüküne ve bitki çaylarının hazırlanma şekline bağlı olduğu açıktır. Sicak su ile demlenerek hazırlanan bitki çaylarında yüksek sayıda bakteri bulunabildiği (Wilson vd., 2004) gösterilmiştir. Maserasyon yolu ile hazırlanan bitki çayları önemli düzeyde mikroorganizma barındırabilmekte ve bu şekilde oda sicaklığında demleme, mikroorganizmaların çoğalmasına olanak tanımaktadır. Kaynar su ile hazırlama çoğunlukla mikroorganizma sayısında azalma ve patojenlerin önemli oranda inaktivasyonu ile sonuçlanmakla birlikte, Bacillaceae familyasına ait bakteri sporları infüzyon gibi termal işlemlere direnç göstermekte ve bu termal şok sporların çimlenmesini teşvik edebilmektedir. $\mathrm{Bu}$ bakterilerden bazıları gida zehirlenmelerine yol açmaları ile tanınan $B$. cereus ve $C$. perfringens'dir. Bu nedenle sıcak ya da soğuk suyla hazırlanan bitki çaylarının mikrobiyolojik kontaminasyonu önemlidir (Araujo ve Bauab, 2012). Bazı mikroorganizmaların bitki çaylarının sıcak su ile hazırlanmasından sonra da canlılığını sürdürebilmesi, bazı bakterilerin çaya uygulanan etanol ile ekstraksiyon gibi işlemleri tolere edebilmesi ve çok yüksek sicaklıklara dayanıklı olabilmeleri gibi nedenlerle yüksek miktarda mikrobiyal yüke sahip bitki çaylarının tüketiminin insan sağlı̆̆ açısından risk taşıdığ (Khattak, 2012). Bitki çayları gibi bitkisel materyallerde mikrobiyolojik stabilitenin sağlanması amacıyla önem verilmesi gereken iki üretim basamağı, kurutma ve depolamadır. Bitkinin kullanılacağı kısım, içerdiği aktif bileşenlerin korunması ve nem düzeyi gibi faktörler göz önünde bulundurularak koşulları belirlenen kurutma işleminin, düşük sıcaklıklarda yapılması bitkisel materyalde mikroorganizmaların gelişimine olanak tanımakta, diğer taraftan yüksek sıcaklıkta kurutma toplam aerobik mikroorganizma sayısında azalma sağlamaktadır. Depolama sırasındaki kötü havalandırma koşulları, çoğunlukla nem içeriğinin artmasına yol açmakta ve bu bitkisel materyaller küflerin gelişimi ve toksin üretimine daha elverişli hale gelmektedir. Bağıl nemin kontrol altında tutulmadığı durumlarda, bitkisel materyaldeki en yaygın kontaminantlardan olan küfler 
gelişebilmektedir (Chen ve Mujumdar, 2006; Araujo ve Bauab, 2012). Ülkemiz gida mevzuatında, gidalarda bulunabilecek mikroorganizma düzeylerine ilişkin düzenleme, Türk Gida Kodeksi Mikrobiyolojik Kriterler Yönetmeliği'nde yer almakta olup, bitki çaylarında bulunmasına izin verilen maya küf sayıs $10^{5} \mathrm{kob} / \mathrm{g}$, Salmonella sayıs ise 0/25 g-mL olarak sınırlandırılmıştır (Anonim, 2011a). Dünya Sağl1k Örgütü ise, bitki çayları için aerobik bakteri düzeyini $\leq 10^{7} / \mathrm{g}$, maya ve küf düzeyini $\leq 10^{4} / \mathrm{g}$, Enterobacteriaceae düzeyini $\leq 10^{4} / \mathrm{g}$, Escherichia coli düzeyini $\leq 10^{2} / \mathrm{g}$ olarak belirlemiş ve Salmonella bulunmaması gerektiğini belirtmiştir (Anonim, 1998). Bitki çaylarında toksijenik küflerin varlığını belirlemek amacıyla gerçekleştirilen bir çalışmada Halt (1998), aralarında 1hlamur ve kuşburnunun da yer aldığı 73 örneği incelemiş, en baskın küflerin, örneklerin \%54,58'inde bulunan Penicillium spp. ve \%19,80'inde bulunan Aspergillus spp. olduğunu, en önemli aflatoksin üreticilerinden Aspergillus flavus'un örneklerin \%16'sinda bulunduğunu tespit etmiştir. Aynı amaçla gerçekleştirilen bir başka çalışmada, market ve pazardan temin edilen 15 türe ait 47 bitki çayı örneğini inceleyen Bokhari ve Aly (2013), baskın mikroflorayı 13 cins ve 25 türün oluşturduğunu, mikotoksikolojik açıdan son derece önemli kabul edilen Aspergillus, Penicillium ve Fusarium cinslerinin en fazla bulunan küfler olduğunu tespit etmiştir. Her bitki çayına ait en az bir örneğin, adaçayı, kakule, kaktüs ve krizantem örneklerinin ise tamamının küfler ile kontamine olduğunun belirlendiği çalışmada, küf kontaminasyonunun $4,4 \times 10^{4} \mathrm{kob} / \mathrm{g}$ 'a ulaştığ 1 belirlenmiş olup, buradan hareketle araştırmacılar, toksijenik küflerin varlığının mikotoksin kontaminasyonu için potansiyel bir risk oluşturduğunu ve tüketici sağlığ1 açısından riskleri azaltmak amaciyla işlenmemiş bitkisel çaylardaki toksijenik küfler için standartların düzenlenmesi gerektiğini belirtmiştir. Ülkemizde adaçayı, 1hlamur ve nane ile bunlardan hazırlanan infüzyonlarda, Özyaral vd. (1994) tarafından mikolojik analiz yapılmış ve flora kaybı incelenmiştir. 27 örneğin incelendiği çalışmada, 27 ayrı türe ait toplam 122 adet küf izole edilmiş ve bunlardan 81 adedinin \%33,6'lık bir kayıpla infüzyonlarda canlı kaldığı belirlenmiştir. Baskın mikroflorayı içinde önemli aflatoksin üreticisi $A$. flavus ve A. parasiticus'un da yer aldiğ 1 Aspergillus'ların oluşturduğu saptanmış olup, bu gibi ürünlerin kurutma, depolama, ambalajlama ve tüketime kadar geçen süre boyunca küf ve dolayısıyla toksinleri ile kontamine olarak sağlığ tehdit edebileceği vurgulanmıştır. Benzer şekilde aralarında 13 adet hlamur, 13 adet papatya, 2 adet adaçay 1 ve 2 adet nanenin de yer aldı ğ 1 toplam 62 adet tıbbi bitki örneğinin mikrobiyal kalitesini belirlemek amaciyla Martins vd. (2001b) tarafından yapılan bir çalışmada, \%93,5'inin fungal kontaminasyona maruz kaldı̆̆ saptanan örneklerde Fusarium spp., Penicillium spp., A. flavus ve A. niger'in baskın küfler olduğu tespit edilmiş, 1hlamurun A. flavus ile en yüksek düzeyde kontamine olmuş örnekler arasında ikinci sırada yer aldığ 1 belirlenmiştir. Ayrıca tamamına yakınının $(\% 96,8)$ B. cereus ve büyük bir k1smının $(\% 83,9)$ C. perfringens gibi patojen bakteriler ile kontamine olduğu belirlenen örneklerin çizdiği mikrobiyolojik tablo nedeniyle yüksek risk oluşturdukları ve bu nedenle bu tip ürünlere yönelik hijyenik uygulamalar ile dekontaminasyon yöntemlerinin geliştirilmesi gerektiği bildirilmiştir. $\mathrm{Bu}$ ürünlerde Aspergillus, Fusarium ve Penicillium cinslerinin en s1k karşılaşılan küfler olduğunu gösteren bir başka çalışmada Abou Donia (2008), Misır'da bazı baharat ve bitki çaylarına ait 303 örneği incelemiş, incelenen tüm örneklerde söz konusu küflerin bulunduğunu tespit eden araştırmacı, en yüksek oranda küf barındıran tıbbi bitkinin rezene olduğunu, $A$. flavus ve $A$. niger'in en baskın türler olduğunu ortaya koymuştur. Abou-Arab vd. (1999) tarafindan 
yapılan çalışmada ise ıhlamur, papatya, nane, kimyon ve anasondan oluşan 20 örnek fungal kontaminasyon açısından değerlendirilmiş ve Aspergillus ve Penicillium'un en s1k karşılaşılan cinsler olduğu, A. flavus'un ise biri dışında tüm örneklerde bulunduğu ve çoğu örnekte en baskın tür olduğu belirlenmiştir. Aralarında rezene gibi bitki çaylarının da yer aldığı tıbbi bitkilerin güvenilirliğini belirlemek amaciyla gerçekleştirilen bir çalışmada 38 türden 63 tıbbi bitki örneği incelenmiştir. Küf kontaminasyonunun, 58 örnekte $5 \times 10^{1}-5 \times 10^{4}$ $\mathrm{kob} / \mathrm{g}$ düzeyinde ve örneklerin $\% 47$ 'sinde Dünya Sağlık Örgütü tarafından belirlenen limitlerin üzerinde olduğunu saptayan araştırmacılar, Aspergillus, Penicillium, Mucor, Cladosporium, Fusarium, Alternaria ve Rhizopus cinslerine ait 187 küfün izole edildiğini, örneklerin \%66,66'sında bulunan A. niger'in en yaygın bulunan tür olduğunu belirlemiş, izole edilen küfler içerisinde, 19 $\mathrm{AFB}_{1}$ üretici $A$. flavus ve 9 sitrinin üretici Penicillium citrinum tespit etmiştir (Aiko ve Mehta, 2016). Řezáčová ve Kubátová (2005), Prag'da yerel marketlerden ambalajlı ve ambalajsız olarak temin ettikleri siyah çay, yeşil çay ve papatya, melisa, mürver, 1sırgan otu, rooibos, sinameki, hibiskus, mate, rezene, ıhlamur gibi bitki çaylarında küf varlığını araştırmıştır. Tamamının kontamine olduğu belirlenen 40 örneğin incelendiği çalışmada, 81 küf türü tespit edilmiştir. Araştırmacılar tarafindan bunlar arasında, en önemlilerinin potansiyel aflatoksijenik A. flavus, okratoksijenik A. ochraceus, A. niger ve sterigmatosistin üretebilen $A$. versicolor olduğu bildirilen, çok sayıda toksijenik küfün yer aldığı belirtilmiştir. Benzer bir çalışmada Romagnoli vd. (2007), tıbbi ve aromatik bitki ile bitki çaylarına ait 27 örneği küflerin varlığını araştırmak için bir mikrobiyolojik incelemeye tabi tutmuştur. İtalya Cumhuriyeti Resmi Farmakopesi (9. Basım) bitki infüzyonları ve dekoksiyonlarında küfler için limit değerleri $10^{4} \mathrm{kob} / \mathrm{g}$ olarak belirlemiş olduğundan, örneklerin \%56'sının aflatoksin içermese bile küfler tarafından kontamine edildiği sonucu ortaya konmuştur. Scolari vd. (2001), çay ve 1hlamur, nane, papatya gibi bitki çaylarına ait 85 örneği incelemiştir. Bu çalışmada örneklerin \%86'sının mikroorganizmalar ile kontamine olduğu ve bitki çaylarında $10^{6} \mathrm{kob} / \mathrm{g}$ 'a varan düzeyde toplam mezofilik aerobik bakteri ve $10^{1}-10^{4}$ kob/g düzeyinde koliform grubu bakteri bulunduğu tespit edilmiştir. Miktarı $10^{0}-10^{4}$ kob/g olarak belirlenen aerobik sporlu bakterilerin \%40'ını Bacillus cinsinin oluşturduğunu, en yüksek küf düzeyine $2,0 \times 10^{4} \mathrm{kob} / \mathrm{g}$ ile papatyanın sahip olduğunu saptayan araştırmacılar, bitki çaylarının diğer çay örneklerine göre daha yüksek düzeyde mikroorganizma barındırdığını ortaya koymuştur. 69 adet bitki çayı örneğinde fungal kontaminasyon ve toplam mezofilik aerobik bakteri sayısının araştırıldığı bir başka çalışmada ise, Tournas ve Katsoudas (2008), örneklerde $5,8 \times 10^{5} \mathrm{kob} / \mathrm{g}$ 'a varan düzeyde fungal kontaminasyon tespit etmiştir. $A$. flavus, A. niger, A. carbonarius, A. versicolor, A. ochraceus, Fusarium, Penicillium spp. gibi potansiyel mikotoksin üreticilerinin yanı sıra, örneklerin maya ve $1,2 \times 10^{7} \mathrm{kob} / \mathrm{g}$ gibi yüksek düzeyde toplam mezofilik aerobik bakteri barındırdığı bildirilmiştir. Omogbai ve Ikenebomeh (2013), Nijerya'da farklı amaçlarla kullanılan 5 farklı tip bitki çayına ait 27 örneği bakteri ve küf kontaminasyonu yönünden incelemiş, aralarında Staphylococcus aureus, Salmonella typhimurium gibi patojenlerin de bulunduğu

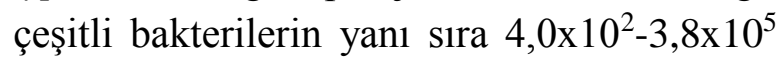
$\mathrm{kob} / \mathrm{g}$ düzeyinde küf tespit etmiştir. Baskın küf mikroflorasını sirasıyla A. niger, A. flavus ve $P$. expansum'un oluşturduğunu bildiren araştırmacilar, aflatoksin üretme olasılığ nedeniyle A. flavus gelişiminin önlenmesi amacıyla bu tip ürünlerin hızlı bir şekilde kurutulmasının önemine değinmiştir. Stević vd. (2012) tarafından gerçekleştirilen, 40'1n üzerinde türden tıbbi bitkide bulunan bakteri ve küflerin izolasyonu ve tanımlanmasının amaçlandığı bir çalışmada, bazı örneklerin 
toplam mezofilik aerobik bakteri ve maya küf düzeyi yönünden farmakope ve yönetmeliklerde belirtilen limitleri aştı̆̆ saptanmıştır. Örneklerin çoğunda Bacillus ve Clostridium cinslerine ait türlerin en baskın bakteriler olduğu ve aralarında hhlamur ve nanenin de yer aldığı bazı örneklerde çok sayıda E. coli gibi patojenik bakteri tespit edilmiştir. Örneklerde $10^{6} \mathrm{kob} / \mathrm{g}^{\prime} 1$ bulan düzeyde küf saptanmış, en baskın türlerin ise Fusarium ve Aspergillus olduğu belirlenmiştir. Bitki çaylarına ait genel mikrobiyolojik tabloyu ortaya koyan Arslan (2013), organik tarım yöntemleri ile üretilen ve organik sertifikaya sahip bazı baharat ve dağ/ada çayı, ıhlamur, kuşburnu, papatya, rezeneden oluşan bitkisel çay örneklerinde, küf-maya, S. aureus, Enterobactericeae, koliform bakteri seviyelerini belirlemeye yönelik bir çalışma yapmıştır. Mikrobiyolojik sayımları hizlı mikrobiyolojik analiz yöntemiyle gerçekleştirmiş, analizi yapılan 37 bitkisel çayın 30 tanesinde (\%82) maya küf kontaminasyonu tespit etmiştir. En yüksek kontaminasyon seviyesine, ihlamurun $\left(3,5 \times 10^{3} \mathrm{kob} / \mathrm{g}\right)$, en düşük seviyeye ise kuşburnunun $\left(1,1 \times 10^{1} \mathrm{kob} / \mathrm{g}\right)$ sahip olduğunu belirlemiştir. Örneklerin kontaminasyon seviyelerini, dağ/ada çayında $1,0 \times 10^{1}-3,0 \times 10^{3}$ $\mathrm{kob} / \mathrm{g}$, 1hlamurda $3,3 \times 10^{2}-5,2 \times 10^{3} \mathrm{kob} / \mathrm{g}$, kuşburnunda $\quad<1,0 \times 10^{1}-2,1 \times 10^{1} \quad \mathrm{kob} / \mathrm{g}$, papatyada $<1,0 \times 10^{1}-8,3 \times 10^{3} \mathrm{kob} / \mathrm{g}$, rezenede $5,5 \times 10^{1}-8,2 \times 10^{3} \mathrm{kob} / \mathrm{g}$ olarak tespit etmiştir. Analiz ettiği 37 bitkisel çay örneğinin 33 tanesinde $(\% 89,19)$ S. aureus, 36 tanesinde $(\% 97,29)$ Enterobecteriaceae ve 25 tanesinde $(\% 67,56)$ koliform bakteri saptamış olup, maksimum kontaminasyon seviyesinin $S$. aureus için kontaminasyon seviyesi ortalamasina göre $>4,9 \times 10^{4} \mathrm{kob} / \mathrm{g}$ ile dağ/ada çay1, kuşburnu ve papatyada, Enterobecteriaceae için $>4,9 \times 10^{4} \mathrm{kob} / \mathrm{g}$ ile kuşburnunda, koliform bakteriler için ise $4,16 \times 10^{4} \mathrm{kob} / \mathrm{g}$ ile kuşburnunda görüldüğünü, minimum bakteriyel kontaminasyonun ise bitkisel çaylar içinde rezeneye ait olduğunu bildirmiştir. Benzer bir çalışma HIV taşıyan $\begin{array}{llr}\text { bireyler tarafindan çay } & \text { formunda } \\ \text { kullanılabilen bitkisel } & \text { materyallerin }\end{array}$ mikrobiyolojik kalitesini belirlemek amacıyla gerçekleştirilmiş, örneklerde toplam aerobik bakteri, koliform, E. coli, S. aureus ve maya küf sayımı yapılmıştır. Araştırmacılar tarafindan toplam aerobik bakteri sayıs1 $1,5 \times 10^{1}-7,1 \times 10^{8} \mathrm{kob} / \mathrm{g}$, toplam ve fekal koliform say1s1 $<10-3 \times 10^{6} \mathrm{kob} / \mathrm{g}$, E. coli sayıs $<10-5 \times 10^{1} \mathrm{kob} / \mathrm{g}$ ve $S$. aureus say1s1 $<10$ $2,5 \times 10^{3} \mathrm{kob} / \mathrm{g}$, maya ve küf say1s1 $<10-9 \times 10^{4}$ $\mathrm{kob} / \mathrm{g}$ olarak tespit edilmiş olup, toplam aerobik bakteri, koliform ve maya küf sayım sonuçları açısından değerlendirildiğinde sirasıyla örneklerin $\% 4, \% 13$ ve $\% 13$ 'ünün Dünya Sağlık Örgütü tarafından bitki çayı ve infüzyonlarında bulunmasına izin verilen limitlerin üzerinde mikroorganizma içerdiği bildirilmiştir (Kaume vd., 2012). Literatürde bitki çaylarından izole edilen toksijenik küflerin, mikotoksin üretme potansiyelleri yönünden incelendiği çalışmalar da bulunmaktadır. Storari vd. (2012) tarafından İsviçre'de geleneksel olarak tüketilen, çoğunluğunu kuşburnu ve ihlamurun oluşturduğu bitkisel çay örneklerinde siyah Aspergillus'ların izolasyonu ve karakterizasyonunun gerçekleştirildiği bir çalışmada, potansiyel toksijenik izolatlar mikotoksin üretimi açısından in vitro test yöntemleri ile analiz edilmiştir. 22 örnekten 16 'sında $10^{1}-3,5 \times 10^{3} \mathrm{kob} / \mathrm{g}$ düzeyinde siyah Aspergillus kontaminasyonu belirlenmiş ve bunların çoğunlukla küfler arasında baskın mikroflorayı oluşturdukları belirtilmiştir. İncelenen bitkisel çayların aynı zamanda Penicillium ve Fusarium gibi diğer potansiyel toksijenik küfler ile değişen miktarlarda kontamine olduğu bulunmuştur. En s1k bulunan türler, A. niger (41 izolat), A. acidus (39) A. awamori (27) ve A. tubingensis (23) olmuştur. Şarapta OTA kontaminasyonunun birincil nedeni olduğu düşünülen önemli OTA üretici tür $A$. carbonarius hiçbir örnekten izole edilmemiş, iki örnekte potansiyel aflatoksin üreticisi $A$. flavus ve $A$. pseudotamari'ye rastlanmıştır. A. niger ve $A$. 
awamori, fumonisin ve OTA üretme yeteneklerini incelemek üzere in vitro test edilmiştir. A. niger izolatlarının \%76'sının ve A. awamori izolatlarının $\% 37$ 'sinin fumonisin ürettiği, fumonisin $\mathrm{B}_{2}\left(\mathrm{FB}_{2}\right)$ 'nin yanı sira neredeyse tüm izolatların fumonisin $\mathrm{B}_{4}\left(\mathrm{FB}_{4}\right)$ $\begin{array}{llll}\text { ve fumonisin } & \mathrm{B}_{6} & \left(\mathrm{FB}_{6}\right) & \text { ürettiği }\end{array}$ gözlemlenmiştir. Toplamda 22 örnekten 12 'sinin fumonisin üretebilen siyah Aspergillus'lar ile kontamine olduğu tespit edilen çalışmada, iki farklı çay örneğinden üç A. niger'in (\%7) OTA ürettiği, hiçbir $A$. awamori'nin ise OTA üretmediği bildirilmiştir. Rizzo vd. (2004) tarafından, 13 işletmeden temin edilen 56 tıbbi bitki türüne ait 152 kurutulmuş hammaddede toksijenik Aspergillus, Penicillium ve Fusarium suşlarının varlığı ve in vitro şartlarda mikotoksin üretme yetenekleri araştırılmıştır. $\mathrm{AFB}_{1}, \mathrm{AFB}_{2}, \mathrm{AFG}_{1}, \mathrm{AFG}_{2}$ ve trikotesen tespiti için TLC, OTA ve $\mathrm{FB}_{1}$ ile $\mathrm{FB}_{2}$ tespiti için HPLC kullanılmıştır. Örneklerden izole edilen 40 A. flavus ve A. parasiticus suşunun $\% 50$ 'sinin aflatoksinleri ürettiği belirlenmiştir. Farklı örneklerden izole edilen A. flavus suşlarının $2000 \mu \mathrm{g} / \mathrm{kg}$ 'a kadar $\mathrm{AFB}_{1}$ ve $\mathrm{AFB}_{2}$, A. parasiticus suşlarının 2000 $\mu \mathrm{g} / \mathrm{kg}$ 'a kadar $\mathrm{AFB}_{1}, \mathrm{AFB}_{2}, \mathrm{AFG}_{1}, \mathrm{AFG}_{2}$ ürettiği tespit edilmiştir. Melisa ve ihlamurdan izole edilen A. flavus'ların 100-1000 $\mu \mathrm{g} / \mathrm{kg}$ düzeyinde $A_{F B}$ ve $A F B_{2}$, yine melisa ve hlamurdan izole edilen $F$. verticillioides' in sirasiyla $\quad 4-0,150 \quad \mu \mathrm{g} / \mathrm{kg}, \quad 0,9-0,350 \quad \mu \mathrm{g} / \mathrm{kg}$ aralığında $\mathrm{FB}_{1}$ ve $\mathrm{FB}_{2}$ ürettiği belirlenmiştir. Hindistan'da yapılan bir çalışmada, yeşil kakule, siyah kakule, küçük hindistan cevizi, tarçın ve karanfilden oluşan, çay formunda tüketilebilen 219 örnekte potansiyel mikotoksin üretici küfler ve mikotoksin üretme yetenekleri araştırılmıştır. Aspergillus, Penicillium, Fusarium, Rhizopus, Mucor cinslerine ait 16 türün izole edildiği çalışmada, 5 çeşit örneğin tamamında $A$. paraciticus, A. niger, A. flavus, $P$. citrinum, $P$. verrucosum ve $F$. oxysporum'un bulunduğu, bunlardan $A$. flavus ve $A$. niger'in en baskin türler olduğu belirlenmiştir. A. niger, A. ochraceus, $P$. citrinum ve $P$. verrucosum, OTA ve sitrinin üretme potansiyelleri açısından incelenmiş ve $A$. niger'in \%33,3'ünün, A. ochraceus'un \%25,7'sinin, $P$. verrucosum'un \%36,8'inin OTA, $P$. citrinum'un \%51,4'ünün, $P$. verrucosum'un $\% 13,1$ 'inin sitrinin ve $P$. verrucosum'un \%36,8'inin OTA üretebildiği tespit edilmiştir (Jeswal ve Kumar, 2013).

\subsection{Bitki Çaylarında Mikotoksinler}

Bitki çayları çeşitli yollarla mikroorganizma kontaminasyonuna uğrayabilmekte, bu mikroorganizmalar arasında da küfler önemli bir yer tutmaktadır (Santos vd., 2013). Küfler, bitki çaylarının doğal florasında bulunabildiği gibi, bu ürünlere hava ve toprak yoluyla da bulaşabilmektedir (Araujo ve Bauab, 2012). Fiziksel olarak zarar görmüş bir mahsulün, toprak ile temas halinde iken mikotoksijenik küfler ile bulaşma oranı yüksek olmaktadır. Küflerin varlığı daima mikotoksinlerin de olduğu anlamına gelmemekte ancak mikotoksin tehlikesine işaret etmektedir. Çoğu zaman insanoğlunun kontrolü dişında gelişen çevresel koşulların, küflerin gelişimi için uygun olduğu durumlarda, hasat öncesinde mikotoksin üretimi meydana gelebilmektedir (Heperkan, 2006). Öte yandan bu tür ürünlerin hasat, kurutma, depolama, nakliye gibi üretim ve üretim sonrası işlemler sırasında uygun olmayan koşullara maruz bırakılması da, küf gelişimine ve sonraki aşamada mikotoksin oluşumuna yol açabilmektedir (Santos vd., 2013). Depolama koşulları, özellikle yığınlar halinde depolamada küf gelişimini teşvik etmektedir (Heperkan, 2006). Sicaklık ve nem kontrolü yapılmaksızın uzun süre kötü koşullarda depolanan bitki çayları küf gelişimi ve mikotoksin üretimine uygun hale gelmektedir (Araujo ve Bauab, 2012). Nitekim bitki çaylarında mikotoksinlerin varlığının araştırılmasına yönelik ülkemizde ve yurt dişında yapılmış çeşitli çalışmalar bulunmaktadır. Tablo 1'de bu çalışmalardan bazılarına yer verilmiştir. Ülkemizde 
gidalarda bulunabilecek mikotoksinlerin maksimum limitleri ile ilgili yasal düzenleme "Türk Gıda Kodeksi Bulaşanlar Yönetmeliği”nde yer almaktadır. $\mathrm{Bu}$ yönetmeliğin ekinde bazı gıdalarda bulunmasina izin verilen maksimum aflatoksin, OTA, patulin, deoksinivalenol (DON), zearalenon (ZEA) ve fumonisin limitlerine yer verilmiştir. Buna göre maksimum limitler, kurutulmuş meyvelerde (doğrudan insan tüketimine sunulan veya gida bileşeni olarak kullanılan), $\mathrm{AFB}_{1}$ için 8,0 $\mu \mathrm{g} / \mathrm{kg}$, toplam aflatoksin $\left(\mathrm{B}_{1}+\mathrm{B}_{2}+\mathrm{G}_{1}+\mathrm{G}_{2}\right)$ için $10,0 \mu \mathrm{g} / \mathrm{kg}$, bazı baharatlarda $\mathrm{AFB}_{1}$ için 5,0 $\mu \mathrm{g} / \mathrm{kg}$, toplam aflatoksin için $10 \mu \mathrm{g} / \mathrm{kg}$ olarak belirlenmiştir (Anonim, 2011b). Avrupa Birliği mevzuatında ise bu mikotoksinlere ek olarak T-2 ve HT-2 toksin ile sitrinin limitleri yer almaktadır. Bu mevzuatta ülkemizdeki düzenlemeye benzer şekilde baharatlar için $\mathrm{AFB}_{1}$ seviyesi 5,0 $\mu \mathrm{g} / \mathrm{kg}$, toplam aflatoksin seviyesi $10 \mu \mathrm{g} / \mathrm{kg}$ olarak belirlenmiştir. Farklı olarak, incir dışında kalan ve doğrudan insan tüketimine sunulan veya gıda bileşeni olarak kullanılan kurutulmuş meyvelerde $\mathrm{AFB}_{1}$ düzeyi 2,0 $\mu \mathrm{g} / \mathrm{kg}$, toplam aflatoksin düzeyi 4,0 $\mu \mathrm{g} / \mathrm{kg}$ olarak sınırlandırılmıştır (Anonim, 2006). Ancak bitki çaylarına yönelik bir düzenleme ne ülkemiz ne de Avrupa Birliği mevzuatında mevcuttur. Can ve Duraklı Velioğlu (2016) tarafından ülkemizde yapılan bir çalışmada, hhlamur ve kuşburnunda HPLC ile $\mathrm{AFB}_{1}, \mathrm{AFB}_{2}, \mathrm{AFG}_{1}$ ve $\mathrm{AFG}_{2}$ varlı̆g araştırılmıştır. Örneklerin tamamında, incelenen aflatoksinlerden en az birinin tespit edilebildiği çalışmada, analiz edilen thlamur örneklerinin \%47'sinde yalnızca $\mathrm{AFG}_{2}$ ve kuşburnu örneklerinin \%87'sinde yalnızca $\mathrm{AFG}_{1}$ veya $\mathrm{AFG}_{2}$ saptanmıştır. İki adet 1hlamur örneğinin tayin limitinin $\left(\mathrm{AFG}_{1}\right.$ ve $\mathrm{AFG}_{2}$ için sirasıyla 0,$156 ; 0,162 \mu \mathrm{g} / \mathrm{kg}$ ) üzerinde aflatoksin içerdiği belirlenmiş olup, bunlardan birinde $0,158 \mu \mathrm{g} / \mathrm{kg} \mathrm{AFG}_{1}$ ve 0,168 $\mu \mathrm{g} / \mathrm{kg} \mathrm{AFG}$, diğerinde ise $0,162 \mu \mathrm{g} / \mathrm{kg} \mathrm{AFG}_{2}$ belirlenmiş, bu ürünlerin düşük düzeyde de olsa aflatoksinleri içerebildiği ifade edilmiştir. $\mathrm{Bu}$ ürünlerde yasal limitlerin üzerinde aflatoksin tespit edilen çalışmalar da bulunmaktadır. Ihlamur, papatya, zencefil, keten tohumu, lavanta, biberiye, fesleğen, adaçay1, kekikotu, sinameki, melisa ve rezeneden oluşan 48 işlenmemiş bitki çayı örneğinin HPLC ile $\mathrm{AFB}_{1}, \mathrm{AFB}_{2}, \mathrm{AFG}_{1}$ ve $\mathrm{AFG}_{2}$ varlığ1 yönünden incelendiği bir çalışmada, toplam 43 örnekte aflatoksin tespit edildiği, $\mathrm{AFB}_{1}, \quad \mathrm{AFB}_{2}, \quad \mathrm{AFG}_{1}$ ve $\mathrm{AFG}_{2}$ kontaminasyon seviyelerinin sirasiyla $0-14,2$, $0-12,4,0-13,5$ ve $0-28,7 \mu \mathrm{g} / \mathrm{kg}$ arasinda değiştiği ve en yüksek aflatoksin konsantrasyonuna $(34,18 \mu \mathrm{g} / \mathrm{kg})$ bir papatya çay1 örneğinde rastlanıldığ 1 bildirilmiştir (Tosun vd., 2016). Bir diğer çalışmada Arslan (2013), organik tarım yöntemleri ile üretilen ve organik sertifikaya sahip 93 baharat ve 9 dağ/ada çayı, 5 ihlamur, 6 kuşburnu, 10 papatya, 7 rezeneden oluşan 37 bitkisel çay örneğini incelemiştir. ELISA testinin kullanıldığı çalışmada, incelenen organik bitkisel çay örneklerinin \%86'sında $\mathrm{AFB}_{1}$ tespit edilmiş ve $\mathrm{AFB}_{1}$ düzeylerinin, 1hlamurda $0,051-40,647 \mu \mathrm{g} / \mathrm{kg}$, kuşburnunda $20,695-52,500 \mu \mathrm{g} / \mathrm{kg}$, rezenede $1,069-11,034$ $\mu \mathrm{g} / \mathrm{kg}$, papatyada 3,438-38,877 $\mu \mathrm{g} / \mathrm{kg}$, dağ/ada çayında $0,246-32,239 \mu \mathrm{g} / \mathrm{kg}$ olduğu bildirilmiştir. Öte yandan Dağdelen vd. (2014), ulusal çapta üretimde önemli yeri olan bir firmadan 2010 y1lı mahsulü ham ve paketlenmiş halde tedarik ettikleri adaçayı, 1hlamur, kuşburnu, papatya ve rezenenin $\mathrm{AFB}_{1}, \mathrm{AFB}_{2}, \mathrm{AFG}_{1}, \mathrm{AFG}_{2}$ düzeylerini HPLC ile belirledikleri çalışmalarında, analiz edilen ham numunelerde ve raf ömürleri boyunca periyodik olarak $1,12,18,24,28,32$ ve 36 . aylarda analiz edilen paketlenmiş örneklerdeki aflatoksin düzeyinin ölçüm limitinin altında olduğunu bildirmiştir. Ülkemizde yapılan bir diğer çalışmada Omurtag ve Yazıcıoğlu (2004), İstanbul'daki market ve pazarlardan temin ettikleri 54 bitki çayı ve Türkiye'de birçok insan tarafından kullanılan doğal infüzyonlardan olan 61 tıbbi bitki örneğinde HPLC ile $\mathrm{FB}_{1}$ ve $\mathrm{FB}_{2}$ varlığını araştırmıştır. Siyah çay, yeşil çay, defne, mısır püskülü, papatya, kuşburnu, dağçayı, ıhlamur, 
adaçay1, nane, 1sırgan otu, sinameki, kekik, rezene, meyankökü, maydanoz-mısır püskülü-kiraz sapı-biberiye-rezene karışımı, papatya-mayasılotu karışımı, nane-1sırgan otu karışımı, papatya-rezene-kısamahmut otu karışımının oluşturduğu örneklerden, nane ve 1sirgan otunda sirasiyla 160 ve $1487 \mu \mathrm{g} / \mathrm{kg}$ düzeyinde $\mathrm{FB}_{1}$ tespit edildiği, $\mathrm{FB}_{2}$ 'ye ise hiçbir örnekte rastlanmadığı ortaya konmuştur. Martins vd. (2001a) tarafindan gerçekleştirilen benzer bir çalışmada, Lizbon'daki farklı marketlerden temin edilen 18 portakal ağacı yaprağı, 18 ihlamur, 15 misır püskülü ve 18 papatya örneğinden oluşan 69 tıbbi bitki ile 18 siyah çay örneği olmak üzere toplam 87 örnekte $\mathrm{FB}_{1}$ ve $\mathrm{FB}_{2}$ düzeyi HPLC ile incelenmiştir. 57 örnekte $(\% 65,5) \quad \mathrm{FB}_{1} \quad$ içeriğinin $\quad 20-700 \quad \mu \mathrm{g} / \mathrm{kg}$ düzeyinde olduğu, hiçbir örnekte $\mathrm{FB}_{2}$ 'ye rastlanmadığ 1 belirtilen çalışma sonucunda, tıbbi bitkilerden \%66,6'sının $\mathrm{FB}_{1}$ içerdiği belirlenmiştir. Portakal ağacı yapraklarının $350-700 \mu \mathrm{g} / \mathrm{kg}$ ile en yüksek konsantrasyona sahip olduğu, onu \%66,6'sının $\mathrm{FB}_{1}$ ile kontamine olduğu belirlenen ihlamurun 20$200 \mu \mathrm{g} / \mathrm{kg}$ ile izlediği tespit edilmiştir. Araştırmacılar, mısır püskülü örneklerinin $\% 60,0$ 'ının ve papatya örneklerinin \%44,4'ünün $\mathrm{FB}_{1}$ içerdiğini ve sırasıyla 50$150 \mu \mathrm{g} / \mathrm{kg}$ ve $20-70 \mu \mathrm{g} / \mathrm{kg}$ arasında değişen $\mathrm{FB}_{1}$ konsantrasyonlarına sahip olduklarını bildirmiştir. Suudi Arabistan'da yaşayan yerel halk tarafından tüketilen bitkisel çaylarda $\mathrm{FB}_{1}$ varlığının araştırıldığı bir çalışmada 15 türe ait 47 örnek HPLC ile analiz edilmiştir. Market ve pazarlardan ambalajsız olarak temin edilen örneklerde $\mathrm{FB}_{1}$ düzeyinin ortalama 39,14 $\mu \mathrm{g} / \mathrm{kg}$ olduğu ve $0-266 \mu \mathrm{g} / \mathrm{kg}$ arasında değiştiği, en yüksek $\mathrm{FB}_{1}$ konsantrasyonuna adaçayının sahip olduğu ortaya konmuştur (Bokhari ve Aly, 2013). Tibbi bitkilerin insan sağlığına yönelik olarak mikotoksikolojik açıdan risk taşıyıp taşımadığını belirlemek amacıyla gerçekleştirilen bir çalışmada 1hlamur, sinameki, nane, melisa gibi bitkilerin de yer aldığı 81 örnekte aflatoksin düzeyi araştırılmıştır. Araştırmacılar bitki çayı yapımında kullanılmak üzere hazırlanmış kurutulmuş bitki karışımından oluşan 25 örneği son ürün, bir kısmı doğadan toplanmış bir kısmı serada yetiştirilmiş bir süredir depolanmakta olan 38 örneği ham bitkisel materyal ve doğadan henüz toplanan 18 örneği hasat örnekleri olarak sınıflandırmıştır. Rizzo vd. (1998), ham bitkisel materyal olarak sinıflandırılan örneklerden \%8,7'sinde, turunç meyvesi kabuğu, akdiken kabuğu, ayrık otu ve 1hlamurda $\mathrm{AFB}_{1}$ ve $\mathrm{AFB}_{2}$ tespit edildiğini bildirmiştir. Zhang vd. (2017), çayı yapılarak tüketilebilen 14 tıbbi bitki örneğini HPLC ile $\mathrm{AFB}_{1}, \quad \mathrm{AFB}_{2}, \quad \mathrm{AFG}_{1}, \quad \mathrm{AFG}_{2} \quad$ varlığını belirlemek üzere incelemiş ve küf kontaminasyonu olan bir örnekte, $6,75 \mu \mathrm{g} / \mathrm{kg}$ düzeyinde $\mathrm{AFB}_{1}$ ve tayin limitinin $(1 \mu \mathrm{g} / \mathrm{kg})$ altında $\mathrm{AFB}_{2}$ tespit etmiştir. İran'da yapılan bir çalışmada aralarında bitki çayı olarak tüketilen papatya, adaçayı, rezene ve nanenin de yer aldığı ambalajlı ve ambalajsız olarak temin edilen toplam 120 bitkisel ürün, $\mathrm{AFB}_{1}$, $\mathrm{AFB}_{2}, \mathrm{AFG}_{1}$ ve $\mathrm{AFG}_{2}$ seviyelerini belirlemek amaciyla HPLC ile analiz edilmiştir. İncelenen örneklerden 37 'sinin aflatoksin ile kontamine olduğu ve aflatoksin konsantrasyonunun $0,2-57,5 \mu \mathrm{g} / \mathrm{kg}$ düzeyinde olduğu belirlenen çalışmada, $\mathrm{AFB}_{1}$ ve toplam aflatoksin seviyesinin sirasıyla örneklerin \%13,3 ve \%10'unda Avrupa Birliği tarafından belirlenen limitleri aştığı tespit edilmiştir (Khazaeli vd., 2017). Aralarında sinameki, nane gibi bitki çaylarının da yer aldığı tıbbi bitkilerde aflatoksin varlığının HPLC-MS/MS ile incelendiği, Liu vd. (2012) tarafindan gerçekleştirilen bir çalışmada, analiz edilen 174 örnekten 27'sinin aflatoksin ile kontamine olduğu, örneklerde $\mathrm{AFB}_{1}, \mathrm{AFB}_{2}$, $\mathrm{AFG}_{1}, \mathrm{AFG}_{2}$ görülme sıklı̆̆ ve maksimum düzeylerinin sirasiyla \%15,52, \%14,37, $\% 6,32$ ve $\% 2,30 ; 239,62,13,50,34,21$ ve 3,5 $\mathrm{mg} / \mathrm{kg}$ olduğu belirlenmiştir. Kış kirazı, eğir otu gibi çayı yapılarak tüketilebilen bitkilerden oluşan 6 türe ait 62 örneğin TLC ile $\mathrm{AFB}_{1}$ içeriği yönünden incelendiği bir çalışmada örneklerin ortalama 41-95,4 $\mu \mathrm{g} / \mathrm{kg}$ $\mathrm{AFB}_{1}$ içerdiği belirlenmiştir (Kumar vd., 
2009). Bitki çaylarında, birden fazla türden mikotoksinin varlığının araştırıldığı çalışmalar da bulunmaktadır. Ihlamur ile kuşburnunun da aralarında yer aldığı 62 tıbbi bitki ve 11 bitkisel çay örneğinde küf ve mikotoksin seviyesini araştırdığı çalışmasında Halt (1998), en önemli aflatoksin üreticilerinden $A$. flavus ile kontamine olduğunu belirlediği örneklerden 7'sinde $\mathrm{AFB}_{1}$, OTA ve ZEA mikotoksinlerinin varlığını TLC ile incelemiştir. Söz konusu örneklerde aflatoksine rastlamamış, bir 1hlamur örneğinde eser miktarda OTA tespit etmiştir. Santos vd. (2009), 1hlamur, adaçayı, rezene gibi ülkemizde yaygın olarak kullanılan bitki çaylarının da aralarında yer aldığı 84 tıbbi ve aromatik bitki örneğinin mikotoksin içeriğini ELISA yöntemi ile analiz etmiştir. Araştırmacılar, incelenen 84 numuneden \%99'unun T-2 toksin, \%98'inin ZEA, \%96'sının aflatoksin, \%63'ünün OTA, \%62'sinin DON, \%61'inin sitrinin ve \%13'ünün fumonisin $\mathrm{B} \quad(\mathrm{FB})$ 'ler ile kontamine olduğunu, örneklerin yaklaşık $\% 87$ 'sinin dört veya daha fazla mikotoksini aynı anda içerirken, neredeyse her örnekte aflatoksinlerin, T-2 toksin ve ZEA ile birlikte bulunduğunu, bitkilerde çalışılan mikotoksinler için Avrupa Birliği'nde yasal limitler olmamasına rağmen diğer gıdalar için verilen yasal limitlerle karşılaştırıldığında belirlenen mikotoksin miktarının bazı örneklerde oldukça yüksek olduğunu tespit etmiştir. Ayrıca, adaçayı örnekleri ve papatya örneklerinden birinin, incelenen 7 mikotoksinin tamamı ile kontamine olduğu, adaçayı örneklerinin yüksek aflatoksin $(23,8$ $25,2 \mu \mathrm{g} / \mathrm{kg}) \quad$ ve OTA $(1,1-17,3 \mu \mathrm{g} / \mathrm{kg})$ düzeyine sahip olduğu belirlenmiştir. $\mathrm{Hu}$ ve Rychlik (2014) tarafindan yapılan bir çalışmada, Çin'de nane, zencefil gibi bitki çaylarının da aralarında yer aldığı tıbbi bitkilerde Fusarium mikotoksinleri olan enniatin A (ENN A), enniatin $A_{1}\left(E N N A_{1}\right)$, enniatin $B(E N N B)$, enniatin $B_{1}\left(E N N B_{1}\right)$ ve beauvericin (BEA) varlığ 1 LC-MS/MS ile araştırılmıştır. 60 farklı türden 1'er örneğin analiz edildiği çalışma sonucunda, örneklerin \%25'inin incelenen mikotoksinlerden en az biri ile kontamine olduğu, maksimum ENN A, ENN A 1, ENN B, ENN B 1 , BEA seviyelerinin sirasiyla $355 \mu \mathrm{g} / \mathrm{kg}, 253 \mu \mathrm{g} / \mathrm{kg}, 290 \mu \mathrm{g} / \mathrm{kg}$, $40,2 \mu \mathrm{g} / \mathrm{kg}, 125 \mu \mathrm{g} / \mathrm{kg}$ olarak tespit edildiği, toplam mikotoksin miktarlarının 2,5-751 $\mu \mathrm{g} / \mathrm{kg}$ arasında değiştiği ortaya konmuştur. Hindistan'da yapılan bir çalışmada yeşil kakule, siyah kakule, küçük hindistan cevizi, tarçın ve karanfilden oluşan 219 örnekte potansiyel mikotoksin üretici küfler ile OTA ve sitrinin varlığ 1 araştırılmıştır. Mikotoksin analizinin ELISA testi ile gerçekleştirildiği ve LC-MS/MS ile doğrulandığı çalışma sonucunda, örneklerdeki ortalama OTA ve sitrinin kontaminasyonunun sirasiyla 42-117 $\mu \mathrm{g} / \mathrm{kg}, \quad 0-76 \mu \mathrm{g} / \mathrm{kg}$ arasında değiştiği ve örneklerin büyük çoğunluğunda sitrinin ve OTA'nın birlikte bulunduğu ortaya konmuştur (Jeswal ve Kumar, 2013). Aralarında rezene gibi bitki çaylarının da yer aldığı tıbbi bitkilerin güvenilirliğini belirlemek amaciyla gerçekleştirilen bir çalışmada 38 türden 63 tıbbi bitki örneği incelenmiştir. Örnekler aflatoksin ve sitrinin kontaminasyonu tespiti için HPLC ile analiz edilmiş ve bir örnekte $2,5 \mu \mathrm{g} / \mathrm{kg} \mathrm{AFB}_{1}$ tespit edilmiştir (Aiko ve Mehta, 2016). Literatürde, bitki çaylarında mikotoksin bulunmadığını rapor eden çalışmalar da mevcuttur. Romagnoli vd. (2007), İtalya'daki Emilia Romagna Bölgesindeki pazar, market ve antrepolardan rastgele temin ettikleri, aralarında kuşburnunun da bulunduğu 48 tıbbi bitki ve bitki çayı, 27 aromatik bitki, 28 baharatı HPLC ile aflatoksin tespiti için analiz etmiştir. Analiz edilen 7 baharatın aflatoksin içerdiği, bitki çaylarında ise aflatoksin tespit edilmediği bildirilmiştir. Mısır'da yapılan bir çalışmada Abou-Arab vd. (1999), küçük çocuk ve yetişkinler tarafindan sıklıkla tüketildiğini belirttikleri ihlamur, papatya, nane, kimyon ve anasondan oluşan örnekleri aflatoksin içeriği yönünden incelemiştir. İkisi ambalajlı olmak üzere her bitkiden 4'er örnek, toplamda 20 örneğin incelendiği çalışmada 
araştırmacılar, hiçbir örnekte aflatoksine

rastlanmadığını ortaya koymuştur.

Tablo 1. Bitki çaylarında mikotoksin varlığına yönelik yapılmış çalışmalar

\begin{tabular}{|c|c|c|c|c|c|c|}
\hline Ürün & Mikotoksin & Örnek Sayısı & Pozitif Örnek & $\begin{array}{l}\text { Miktar } \\
(\mu \mathrm{g} / \mathrm{kg})\end{array}$ & Yöntem & Kaynak \\
\hline $\begin{array}{c}\text { Ihlamur } \\
\text { Rezene } \\
\text { Papatya } \\
\text { Dağ/Adaçayı } \\
\text { Kuşburnu } \\
\end{array}$ & $\mathrm{AFB}_{1}$ & 37 & 32 & $\begin{array}{c}0,051-40,647 \\
1,069-11,034 \\
3,438-38,877 \\
0,246-32,239 \\
20,695-52,500\end{array}$ & ELISA & Arslan 2013 \\
\hline $\begin{array}{l}\text { Bitki çayı } \\
\text { Tıbbi bitki }\end{array}$ & $\mathrm{FB}_{1}-\mathrm{FB}_{2}$ & 115 & 2 & $160-1487$ & HPLC & $\begin{array}{c}\text { Omurtag ve } \\
\text { Yazıcıoğlu } 2004\end{array}$ \\
\hline Adaçayı & $\begin{array}{c}\text { OTA } \\
\text { FB'ler } \\
\text { AF'ler } \\
\text { ZEA } \\
\text { T-2 } \\
\text { DON } \\
\text { Sitrinin }\end{array}$ & 2 & 2 & $\begin{array}{c}1,1-17,3 \\
130-133,3 \\
23,8-25,2 \\
4,7-5,2 \\
0,6-2,5 \\
83,6-102,2 \\
51,6-273,2\end{array}$ & ELISA & Santos vd. 2009 \\
\hline Papatya & $\begin{array}{c}\text { OTA } \\
\text { FB'ler } \\
\text { AF'ler } \\
\text { ZEA } \\
\text { T-2 } \\
\text { DON } \\
\text { Sitrinin }\end{array}$ & 2 & 2 & $\begin{array}{c}0,8-1,0 \\
<83,0-90,0 \\
35,8-161,0 \\
7,3-12,5 \\
3,5-8,3 \\
123,4-191,5 \\
31,7-49,3\end{array}$ & ELISA & Santos vd. 2009 \\
\hline $\begin{array}{l}\text { Bitki çay1- } \\
\text { Tıbbi bitki }\end{array}$ & $\begin{array}{l}\mathrm{AFB}_{1} \\
\mathrm{AFB}_{2} \\
\mathrm{AFG}_{1} \\
\mathrm{AFG}_{2}\end{array}$ & 48 & 0 & 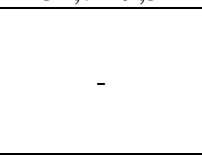 & HPLC & $\begin{array}{c}\text { Romagnoli vd. } \\
2007\end{array}$ \\
\hline Ihlamur & Okratoksin A & 1 & 1 & $\dot{\mathrm{I} z}$ & TLC & Halt 1998 \\
\hline $\begin{array}{c}\text { Siyah çay } \\
\text { Portakal } \\
\text { yaprakları } \\
\text { Ihlamur } \\
\text { Misır püskülü } \\
\text { Papatya }\end{array}$ & $\mathrm{FB}_{1}$ & 87 & 57 & $\begin{array}{c}80-280 \\
350-700 \\
20-200 \\
50-150 \\
50-70\end{array}$ & HPLC & $\begin{array}{l}\text { Martins vd. } \\
\text { 2001a }\end{array}$ \\
\hline $\begin{array}{l}\text { Ihlamur } \\
\text { Kuşburnu }\end{array}$ & $\begin{array}{l}\mathrm{AFB}_{1} \\
\mathrm{AFB}_{2} \\
\mathrm{AFG}_{1} \\
\mathrm{AFG}_{2}\end{array}$ & 30 & 3 & $\begin{array}{l}0,158 \\
0,162\end{array}$ & HPLC & $\begin{array}{c}\text { Can ve } \\
\text { Duraklı } \\
\text { Velioğlu } 2016\end{array}$ \\
\hline $\begin{array}{l}\text { Adaçayı } \\
\text { Ihlamur } \\
\text { Kuşburnu } \\
\text { Papatya } \\
\text { Rezene }\end{array}$ & $\begin{array}{l}\mathrm{AFB}_{1} \\
\mathrm{AFB}_{2} \\
\mathrm{AFG}_{1} \\
\mathrm{AFG}_{2}\end{array}$ & Belirtilmemiş & 0 & - & HPLC & $\begin{array}{c}\text { Dağdelen vd. } \\
2014\end{array}$ \\
\hline $\begin{array}{c}\text { Ihlamur } \\
\text { Papatya } \\
\text { Nane } \\
\text { Anason } \\
\text { Kimyon }\end{array}$ & $\begin{array}{l}\mathrm{AFB}_{1} \\
\mathrm{AFB}_{2} \\
\mathrm{AFG}_{1} \\
\mathrm{AFG}_{2}\end{array}$ & 20 & - & - & - & $\begin{array}{c}\text { Abou-Arab vd. } \\
1999\end{array}$ \\
\hline $\begin{array}{l}\text { Ihlamur } \\
\text { Sinameki } \\
\text { Nane vb. }\end{array}$ & $\begin{array}{l}\mathrm{AFB}_{1} \\
\mathrm{AFB}_{2}\end{array}$ & 81 & 0 & - & TLC & Rizzo vd. 1998 \\
\hline T1bbi bitki & $\begin{array}{l}\mathrm{AFB}_{1} \\
\mathrm{AFB}_{2} \\
\mathrm{AFG}_{1} \\
\mathrm{AFG}_{2}\end{array}$ & 14 & 1 & 67,5 & HPLC & Zhang vd. 2017 \\
\hline $\begin{array}{c}\text { Ihlamur, } \\
\text { papatya, } \\
\text { adaçay1, } \\
\text { rezene vb. } \\
\text { bitki çayları }\end{array}$ & $\begin{array}{l}\mathrm{AFB}_{1} \\
\mathrm{AFB}_{2} \\
\mathrm{AFG}_{1} \\
\mathrm{AFG}_{2}\end{array}$ & 48 & 43 & $12,4-28,7$ & HPLC & Tosun vd. 2016 \\
\hline
\end{tabular}


Bitki Çaylarında Mikrobiyal Kalite ve Mikotoksin Varlığı

\begin{tabular}{|c|c|c|c|c|c|c|}
\hline $\begin{array}{c}\text { Adaçayı, } \\
\text { papatya vb. } \\
\text { bitki çayları }\end{array}$ & $\mathrm{FB}_{1}$ & 47 & 25 & $0-266$ & HPLC & $\begin{array}{c}\text { Bokhari ve Aly } \\
2013\end{array}$ \\
\hline $\begin{array}{c}\text { Papatya } \\
\text { Adaçayı } \\
\text { Rezene } \\
\text { Nane vb. }\end{array}$ & $\begin{array}{l}\mathrm{AFB}_{1} \\
\mathrm{AFB}_{2} \\
\mathrm{AFG}_{1} \\
\mathrm{AFG}_{2}\end{array}$ & 120 & 37 & $0,2-57,5$ & HPLC & $\begin{array}{c}\text { Khazeli vd. } \\
2017\end{array}$ \\
\hline $\begin{array}{l}\text { Sinameki, } \\
\text { nane vb. tibbi } \\
\text { bitkiler }\end{array}$ & $\begin{array}{l}\mathrm{AFB}_{1} \\
\mathrm{AFB}_{2} \\
\mathrm{AFG}_{1} \\
\mathrm{AFG}_{2}\end{array}$ & 174 & 27 & $0,05-290,80$ & $\begin{array}{l}\text { HPLC- } \\
\text { MS/MS }\end{array}$ & Liu vd. 2012 \\
\hline $\begin{array}{l}\text { Nane, zencefil } \\
\text { vb. tıbbi } \\
\text { bitkiler }\end{array}$ & $\begin{array}{c}\text { ENN A } \\
\text { ENN A }_{1} \\
\text { ENN B } \\
\text { ENN B } 1 \\
\text { BEA }\end{array}$ & 60 & 15 & $\begin{array}{c}3,4-354,6 \\
21,7-252,5 \\
3,9-290,5 \\
13,4-40,2 \\
4,6-124,8\end{array}$ & $\begin{array}{c}\text { LC- } \\
\text { MS/MS }\end{array}$ & $\begin{array}{c}\text { Hu ve Rychlik } \\
2014\end{array}$ \\
\hline $\begin{array}{c}\text { Nane, zencefil } \\
\text { vb. } \\
\text { tıbbi bitkiler }\end{array}$ & $\begin{array}{c}\text { OTA } \\
\text { Sitrinin }\end{array}$ & 219 & 144 & $\begin{array}{c}42-117 \\
0-76\end{array}$ & ELISA & $\begin{array}{c}\text { Jeswal ve } \\
\text { Kumar } 2013\end{array}$ \\
\hline $\begin{array}{l}\text { Rezene vb. } \\
\text { tıbbi bitkiler }\end{array}$ & $\begin{array}{l}\text { Aflatoksin } \\
\text { Sitrinin }\end{array}$ & 63 & 1 & 2500 & HPLC & $\begin{array}{l}\text { Aiko ve Mehta } \\
2016\end{array}$ \\
\hline $\begin{array}{l}\text { K1ş kirazı, } \\
\text { eğir otu vb. }\end{array}$ & $\mathrm{AFB}_{1}$ & 64 & Belirtilmemiş & $41-95,4$ & TLC & Kumar vd. 2009 \\
\hline
\end{tabular}

\section{Sonuç ve Tartışma}

Ülkemizde ve dünyada kullanımları giderek yaygınlaşan bitki çaylarının gerek kimyasal gerek biyolojik çeşitli kirliliklere maruz kaldığı bilinmektedir. Bu kirliliklerin arasında mikroorganizmalar önemli bir yere sahiptir. Yapılan çalışmalar, bitki çaylarının birçok mikroorganizmanın yanı sıra özellikle toksijenik küfler ile de kontamine olabildiğini ve küflerin uygun şartlarda bu ürünlerde gelişerek insan sağlığı üzerinde olumsuz etkileri bulunan mikotoksinleri meydana getirebildiğini ortaya koymaktadır. Üretim şekli itibarıyla bunları elimine edebilecek bir işlemden geçmedikleri göz önüne alındığında, insanların kontamine bitki çaylarını tüketmesi sonucu mikotoksinlerin sağlı̆̆a zararlı etkilerine maruz kalabileceğini ifade etmek mümkündür. Alternatif bir sıcak içecek olarak tüketilmesinin yanı sıra hastalıklardan korunmak ve çeşitli hastalıkların tedavisine destek olmak amaciyla da kullanıldıkları düşünüldüğünde, bu ürünlerin tüketimi sonucu mikotoksin tehlikesi ile karşı karşıya kalınabileceğini gösteren çalışmalar, ortaya çıkan çelişkiyi gözler önüne sermektedir. $\mathrm{Bu}$ nedenle, hem diğer mikroorganizmaların hem de küflerin gelişimini minimum düzeyde tutmak ve özellikle de mikotoksin oluşumuna engel olmak amaciyla bu ürünlerin yetiştirilme, hasat, işleme, depolama gibi tüm üretim aşamalarında hijyenik uygulamalara bağlı kalınmalı, mikrobiyal gelişim ve mikotoksin oluşumuna elverişli koşulların ortaya çıkmasına izin verilmemelidir.

\section{Kaynaklar}

Abou-Arab, A.A.K., Kawther, M.S., El Tantawy, M.E, Badeaa, R.İ., Khayria, N. 1999. Quantity estimation of some contaminants in commonly used medicinal plants in the Egyptian market. Food Chemistry, 67, 357-363.

Abou Donia, M.A. 2008. Microbiological quality and aflatoxinogenesis of Egyptian spices and medicinal plants. Global Veterinaria, 2(4), 175-181.

Adams, M.R., Moss, M.O. 2007. Food Microbiology, Third Edition. Royal Society of Chemistry, UK, 478.

Aiko, V., Mehta, A. 2015. Occurrence, detection and detoxification of mycotoxins. Journal of Biosciences, 40(5), 943-954.

Aiko, V., Mehta, A. 2016. Prevalence of toxigenic fungi in common medicinal herbs and spices in India. 3 Biotech, 6, 150-159.

Akgül, A., Ünver, A. 2001. Bitkisel Çaylar. G1da Mühendisliği Dergisi, 11, 21-34. 
Aksoy, H., Yilmaz, S., Çelik, M., Yüzbaşıŏlu, D., Ünal, F. 2008. Moniliformin mikotoksininin in vitro genotoksik etkileri. Sakarya Üniversitesi Fen Edebiyat Dergisi, 10(2), 1-14.

Anonim 1998. Quality control methods for medicinal plant materials. World Health Organization Geneva.

Anonim 2005. General Monographs. Herbal Teas. European Pharmacopoeia 5.0 (01/2005:1435).

Anonim 2006. Setting Maximum Levels for Certain Contaminants in Foodstuffs. Commission Regulation (EC) No $1881 / 2006$ of 19.12 .2006 .

Anonim 2011a. Türk Gida Kodeksi Mikrobiyolojik Kriterler Yönetmeliği. Resmi Gazete: 29.12.2011/ 28157 (3. Mükerrer).

Anonim 2011b. Türk Gıda Kodeksi Bulaşanlar Yönetmeliği, Gıdalardaki Bulaşanların Maksimum Limitleri. Resmi Gazete: 29.12.2011/28157 (3. Mükerrer).

Araújo, M.G.F, Bauab TM. 2012. Microbial Quality of Medicinal Plant Materials. In: Latest Research into Quality Control, (Edited by I. Akyar), InTech, 67-81.

Arslan, R. 2013. Türkiye'de Üretilen Bazı Organik Baharat ve Bitkisel Çayların Aflatoksin $B_{1} \quad$ Düzeyleri ve Mikrobiyolojik Kalitesinin Araştırılması. Yüksek Lisans Tezi, Celal Bayar Üniversitesi, Fen Bilimleri Enstitüsü, Manisa.

Ashiq, S., Hussain, M., Ahmad, B. 2014. Natural occurrence of mycotoxins in medicinal plants: A review. Fungal Genetics and Biology, 66, 1-10.

Atoui, A.K., Mansouri, A., Boskou, G., Kefalas, P. 2005. Tea and herbal infusions: Their antioxidant activity and phenolic profile. Food Chemistry, 89, 27-36.

Aydın, M., Aydın, S., Bacanlı, M., Başaran, N. 2015. Aflatoxin levels in chronic hepatitis B patients with cirrhosis or hepatocellular carcinoma in Balıkesir, Turkey. Journal of Viral Hepatitis, 22, 926-935.

Aydın, M.F., Çelik, İ., Sur, E., Özparlak, H., Telatar, T. 2005. Yumurtaya verilen aflatoksin $\mathrm{B}_{1}{ }^{\prime}$ in civciv çıkış ağırlığ üzerindeki etkileri. Veteriner Bilimleri Dergisi 21(1-2), 85-89.

Bayramoğlu, M.M., Toksoy, D., Şen, G. 2009. Türkiye'de tıbbi bitki ticareti. II. Ormancilikta Sosyo-Ekonomik Sorunlar Kongresi, 19-21 Şubat, Isparta. Belmadani, A., Tramu, G., Betbeder, A.M., Steyn, P.S., Creppy, E.E. 1998. Regional selectivity to ochratoxin A, distribution and cytotoxicity in rat brain. Archives of Toxicology, 72, 656-662.

Bentley, R. 1997. Microbial Secondary Metabolites Play Important Roles in Medicine; Prospects for Discovery of New Drugs. Perspectives in Biology and Medicine, 40(3), 364-394.

Bokhari, F.M., Aly, M.M. 2013. Unexpected hazard due to fumonisins contaminating herbal teas used traditionally by Saudi people. African Journal of Microbiology Research, 7(1), 35-40.

Can, N., Duraklı Velioğlu, S. 2016. Tekirdağ'da satışa sunulan ıhlamur (Tilia spp.) ve kuşburnu (Rosa canina) örneklerinde aflatoksin varlığının araştırılması. Gıda, 42(3), 287-296.

Chan, K. 2003. Some aspects of toxic contaminants in herbal medicines. Chemosphere, 52, 1361-1371.

Chen, G., Mujumdar, A.S. 2006. Drying of Herbal Medicines and Tea, Third Edition. In: Handbook of Industrial Drying, (Edited by A.S. Mujumdar), CRC Press, USA, 635-646.

Çelik, D., Oğuz, H., Demet, Ö., Boydak, M., Dönmez, H.H., Sur, E., Nizamlığlu F. 2000. Embryotoxicity assay of aflatoxin produced by Aspergillus parasiticus Nrrl 2999. British Poultry Science, 41(4), 401-409.

Çelik, M., Yılmaz, S., Aksoy, H., Ünal, F., Yüzbaşığlu, D., Dönbak, L. 2009. Evaluation of the genotoxicity of Fusarium mycotoxin moniliformin in human peripheral blood lymphocytes. Environmental and Molecular Mutagenesis, 50, 431-434.

Dağdelen, A.F., Aşyemez, A.Ü., Tokat, İ.E., Cumbul, D., Dağdelen, A. 2014. Mikrobiyolojik ve aflatoksin yönünden bazı tıbbi ve aromatik bitkiler ve çaylarının incelenmesi. II. Tıbbi ve 
Aromatik Bitkiler Sempozyumu, 23-25 Eylül, Yalova.

Do, K.H., An, T.J., Oh, S.K., Moon, Y. 2015. Nation-based occurrence and endogenous biological reduction of mycotoxins in medicinal herbs and spices. Toxins, 7, 4111-4130.

Dönmez Altuntas H., Gökalp Yıldız, P., Bitgen, N., Hamurcu, Z. 2013. Evaluation of genotoxicity, cytotoxicity and cytostasis in human lymphocytes exposed to patulin by using the cytokinesis-block micronucleus cytome (CBMN cyt) assay. Mycotoxin Research, 29, 63-70.

Durmuş, E., İnan, O., Çelik, I., Sur, E., Özkan, Y., Acar, A., Aydın, M.F. 2005. Use of the fertilized hen's egg in the evaluation of embryotoxicity of dental alloys. Journal of Biomedical Materials Research, 72(B), 322-327.

Erginkaya, Z., Kabak, B. 2010. Fırsatçı Patojenler, Küfler, Parazitler, Virüsler, Prionlar ve Alg Toksinleri. In: Gida Mikrobiyolojisi, (Edited by O. Erkmen), Eflatun Basım, Ankara, Türkiye, 183203.

Faydaoğlu, E., Sürücüoğlu, M.S. 2011. Geçmişten günümüze tıbbi ve aromatik bitkilerin kullanılması ve ekonomik önemi. Kastamonu Üniversitesi Orman Fakültesi Dergisi, 11(1), 52-67.

Gürbüzel, M., Uysal, H., Kizilet, H., 2010. Assessment of genotoxicity of the mycotoxin paxilline using the somatic mutation and recombination test in Drosophila melanogaster. Fresenius Environmental Bulletin, 19, 1038-1041.

Halt, M. 1998. Moulds and mycotoxins in herb tea and medicinal plants. European Journal of Epidemiology, 14, 269-274.

Hayes, A.W., Hood R.D., Lee, H.L. 1974. Teratogenic effects of ochratoxin A in mice. Teratology, 9(1), 93-97.

Heperkan, D. 2006. Detecting and Controlling Mycotoxin Contamination of Herbs and Spices. In: Handbook of Herb and Spices Volume 3, (Edited by K.V. Peter), Woodhead Publishing Limited, Cambridge, England, 3-40.

$\mathrm{Hu}$, L., Rychlik, M. 2014. Occurrence of enniatins and beauvericin in 60 Chinese medicinal herbs. Food Additives \&
Contaminants: Part A, 31(7), 12401245.

Hussein, H.S., Brasel, J.M. 2001. Toxicity, metabolism, and impact of mycotoxins on humans and animals. Toxicology, 167, 101-134.

Huwig, A., Freimund, S., Käppeli, O., Dutler, H. 2001. Mycotoxin detoxication of animal feed by different adsorbents. Toxicology Letters, 122, 179-188.

IARC 2012.2 "Aflatoxins" https://monographs.iarc.fr/ENG/Monog raphs/vol100F/mono100F-23.pdf. Son Erişim Tarihi: 04.07. 2018.

IARC 1993. "Ochratoxin A" https://monographs.iarc.fr/ENG/Monog raphs/vol56/mono56-18.pdf. Son Erişim Tarihi: 04.07. 2018.

IARC 2002. "Fumonisin $\mathrm{B}_{1}$ " https://monographs.iarc.fr/ENG/Monog raphs/vol82/mono82-7B.pdf. Son Erişim Tarihi: 04.07. 2018.

Ivanova, D., Gerova, D., Chervenkov, T., Yankova, T. 2005. Polyphenols and antioxidant capasitiy of Bulgarian medicinal plants. Journal of Ethnopharmacology, 96, 145-150.

Jeswal, P., Kumar, D. 2013. Mycofloral association and co-occurrence of ochratoxin A and citrinin in aromatic herbs and spices from Bihar state (India) detected by ELISA and LC-MS/MS. American Journal of Biological, Chemical and Pharmaceutical Sciences, 1(8), 96-105.

Kaume, L., Foote, J.C., Gbur, E.E. 2012. Microbial contamination of herbs marketed to HIV-infected people in Nairobi (Kenya). South African Journal of Science, 108(9/10), 80-83.

Kaya, D.B. 2006. Piyasada Satışa Sunulan Bazı Bitkisel Çayların Mikrobiyolojik Kalitesi. Yüksek Lisans Tezi, Ankara Üniversitesi, Fen Bilimleri Enstitüsü, Ankara.

Khattak, K.F. 2012. 3Microbiological quality assessment of commercially available medicinal plants in Peshawar city, Pakistan. Pakistan Journal of Botany, 44(4), 1203-1208.

Khazaeli, P., Mehrabani, M., Heidari, M.R., Asadıkaram, G., Ları Najafi, M. 2017. Prevalence of aflatoxin contamination in herbs and spices in different regions 
of Iran. Iranian Journal of Public Health, 46(11), 1540-1545.

Kolb, N. 1999. Microbiological status of untreated herbal materials. Deutsche Lebensmittel-Rundschau, 95(7), 263268.

Kosalec, I., Cvek, J., Tomic, S. 2009. Contaminants of medicinal herbs and herbal products. Archives of Industrial Hygiene and Toxicology, 60, 485-501.

Kökdil, G. 2002. Tıbbi çaylar. Galenova, 1921.

Kumar, A., Shukla, R., Singh, P., Dubey, N.K. 2009. Biodeterioration of some herbal raw materials by storage fungi and aflatoxin and assessment of cymbopogon flexuosus essential oil and its components as antifungal. International Biodeterioration \& Biodegradation, 63, 712-716.

Legnani, P.P., Leoni, E., Righi, F., Zarabini, L.A. 2001. Effect of microwave heating and gamma rradiation on microbiological quality of spices and herbs. Italian Journal of Food Science, 13(3), 337-345.

Liu, L., Jin, H., Sun, L., Ma, S., Lin, R. 2012. Determination of aflatoxins in medicinal herbs by high-performance liquid chromatography-tandem mass spectrometry. Phytochemical Analysis, 23, 469-476.

Marin, S., Ramos., A.J., Cano-Sancho, G., Sanchis, V. 2013. Mycotoxins: Occurrence, toxicology, and exposure assessment. Food and Chemical Toxicology, 60, 218-237.

Martins, M.L., Martins, H.M., Bernardo, F. 2001a. Fumonisins $B_{1}$ and $B_{2}$ in black tea and medicinal plants. Journal of Food Protection, 64, 1268-1270.

Martins, H.M., Martins, M.L., Dias, M.I., Bernardo, F. 2001b. Evaluation of microbiological quality of medicinal plants used in natural infusions. International Journal of Food Microbiology, 68, 149-153.

Megahee, L. 1995. Rediscovering herbal teas. Flower and Garden, 39(4), 52-55.

Omogbai, B.A., Ikenebomeh, M. 2013. Microbiological characteristics and phytochemical screening of some herbal teas in Nigeria. European Scientific Journal, 9(18), 149-160.
Omurtag, G.Z., Yazıcıŏlu, D. 2004. Determination of fumonisins $\mathrm{B}_{1}$ and $\mathrm{B}_{2}$ in herbal tea and medicinal plants in Turkey by high-performance liquid chromatography. Journal of Food Protection, 67, 1782-1786.

Oğuz, H., Hadımlı, H.H., Kurtoğlu, V., Erganiş, O. 2003. Evaluation of humoral immunity of broilers during chronic aflatoxin (50 and $100 \mathrm{ppb}$ ) and clinoptilolite exposure. Revue de Médecine Vétérinaire, 154(7), 483-486.

Öznurlu, Y., Celik, İ., Sur, E., Özaydın, T., Oğuz, H., Altunbaş, K. 2012. Determination of the effects of aflatoxin $\mathrm{B}_{1}$ given in ovo on the proximal tibial growth plate of broiler chickens: histological, histometric and immunohistochemical findings. Avian Pathology, 41(5), 469-477.

Özyaral, O., Tarkan, Ö., Çevikbaş, A., Johansson, C.B. 1994. Farmasötik önemi olan bazı droglarda mikolojik analizler. Mikrobiyoloji Bülteni, 28, 359-365.

Peraica, M., Radic, B., Lucic, A., Pavlovic, M. 1999. Toxic effects of mycotoxins in humans. Bulletin of the World Health Organization, 77(9), 754-766.

Řezáčová, V., Kubátová, A. 2005. Saprobic microfungi in tea based on Camellia sinensis and on other dried herbs. Czech Mycology, 57(1-2), 79-89.

Rizzo, I., Varsavsky, E., Vedoya, G., Haidukowski, M., Frade, H., Chiale, C. 1998. Fungal and aflatoxin contamination of medicinal herbs. Mycotoxin Research, 14, 46-53.

Rizzo, I., Vedoya, G., Maurutto, S., Haidukowski, M., Varsavsky, E. 2004. Assessment of toxigenic fungi on Argentinean medicinal herbs. Microbiological Research, 159, 113120.

Romagnoli, B., Menna, V., Gruppioni, N., Bergamini, C. 2007. Aflatoxins in spices, aromatic herbs, herb-teas and medicinal plants marketed in Italy. Food Control, 18, 697-701.

Sabuncuoğlu, S.A., Baydar, T., Giray, B., Şahin, G. 2008. Mikotoksinler: Toksik etkileri, degredasyonları, oluşumlarının önlenmesi ve zararlı etkilerinin azaltılmas1. Hacettepe Üniversitesi, 
Eczacılık Fakültesi Dergisi, 28(1), 6392.

Santos, L., Marin, S., Sanchis, V., Ramos, A.J. 2009. Screening of mycotoxin multicontamination in medicinal and aromatic herbs sampled in Spain. Journal of the Science of Food and Agriculture, 89, 1802-1807.

Santos, L., Marín, S., Sanchis, V., Ramos, AJ. 2013. Mycotoxin in medicinal/aromatic herbs - a review. Boletín Latinoamericano y del Caribe de Plantas Medicinales y Aromáticas, 12(2), 119142.

Scolari, G., Zacconi, C., Vescovo, M.2001. Microbial contamination of tea and aromatic herb-tea products. Italian Journal of Food Science, 4(13), 429433.

Sezik, E. 2004. Bitkisel Çay Cenneti: Anadolu.http://webnaturel.com/urunbil gi/id/1243/katid/22/ustkatid/1/bitkiselcay-cenneti-anadolu.html (Son Erişim Tarihi: 07.01.2018).

Sezik, E. 2011. Bitkilerin dünyası: Dostlar. Klinik Toksikoloji Derneği 16. Kongresi, 18-21 May1s, Kayseri.

Stević, T., Pavlovic, S., Stankovic, S., Savikin, S. 2012. Pathogenic microorganisms of medicinal herbal drugs. Archives of Biological Sciences, 64(1), 49-58.

Storari, M., Dennert, F.G., Bigler, L., Gessler, C., Broggini, G.A.L. 2012. Isolation of mycotoxins producing black aspergilli in herbal teas available on the Swiss market. Food Control, 26, 157-161.

Sur, E., Celik, İ., Öznurlu, Y., Aydın, M.F., Oğuz, H., Kurtoğlu, V., Özaydın T. 2011. Enzyme histochemical and serological investigations on the immune system from chickens treated in ovo with aflatoxin $\mathrm{B}_{1}\left(\mathrm{AFB}_{1}\right)$. Revue de Médecine Vétérinaire, 162(10), 443448.

Sweeney, M.J., Dobson, A.D.W. 1998. Mycotoxin production by Aspergillus, Fusarium and Penicillium species. International Journal of Food Microbiology, 43, 141-158.

Şişman, T., Yıldırım, Y. 2007. Aflatoksin $\mathrm{B}_{1}{ }^{\prime}$ 'in Zebra balığının (Danio rerio (Hamilton)) embriyo ve larvaları üzerine olan toksik etkileri. Süleyman
Demirel Üniversitesi, Fen Bilimleri Enstitüsü Dergisi, 11(1), 13-17.

Tosun, H., Günç Ergönül, P., Üçok, E.F. 2016. Occurrence of aflatoxins $\left(B_{1}, B_{2}\right.$, $\mathrm{G}_{1}, \mathrm{G}_{2}$ ) in herbal tea consumed in Turkey. Journal für Verbraucherschutz und Lebensmittelsicherheit, 11, 265269.

Tournas, V.H., Katsoudas, E.J. 2008. Microbiological quality of various medicinal herbal teas and coffee substitutes. Microbiology Insights, 1, 47-55.

Tripathy, V., Basak, B.B., Varghese, T.S., Saha, A. 2015. Residues and contaminants in medicinal herbs-a review. Phytochemistry Letters, 14, 6778.

Tschiggerl, C., Bucar, F. 2012. The volatile fraction of herbal teas. Phytochemistry Reviews, 11, 245-254.

Tunail, N. 2000. Funguslar ve Mikotoksinler. In: Gida Mikrobiyolojisi ve Uygulamaları, Genişletilmiş 2. Baskı, Ankara Üniversitesi Ziraat Fakültesi Gıda Mühendisliği Bölümü yayını, Ankara, Türkiye, 3. bölüm, 13. Kısım, $1-50$.

Ulusoy, A., Şeker, M. 2013. Türkiye'de Değişen Çay Tüketim Alışkanlıkları Projesi. Trabzon Ticaret Borsas1.

Vidović, S., Cvetkovic, D., Ramić, M., Dunjić, M., Malbasa, R., Tepić, A., Sumić, Z., Velićanski, A., Jokić, S. 2013. Screening of changes in content of health benefit compounds, antioxidant activity and microbiological status of medicinal plants during the production of herbal filter tea. Industrial Crops and Products, 50, 338-345.

Visconti, A., Minervini, F., Lucivero, G., Gambatesa, V. 1991. Cytotoxic and immunotoxic effects of Fusarium mycotoxins using a rapid colorimetric bioassay. Mycopathologia, 113, 181186.

Vitullo, M., Ripabelli, G., Fanelli, I., Tamburro, M., Delfine, S., Sammarco, M.L. 2011. Microbiological and toxicological quality of dried herbs. Letters in Applied Microbiology, 52, 573-580.

Wilson, D.M., Mubatanhema, W., Jurjevic, Z. 2004. Biology and Ecology of 
Mycotoxigenic Aspergillus Species as

Related to Economic and Health

Concerns. In: Mycotoxins and Food Safety Volume 504, (Edited by J.V. DeVries, M.W. Trucksess, \& L.S. Jackson), Springer Science, New York, USA, 3-17.

Wogan, G.N., Paglialunga, S., Newberne, P.M. 1974. Carcinogenic effects of low dietary levels of aflatoxin $B_{1}$ in rats. Food and Cosmetics Toxicology, 12(56), 681-685.

Zegarac, J.P., Samec, D., Piljac, A. 2013. Herbal Teas: A Focus on Antioxidant Properties. In: Tea in Health and Disease Prevention, (Edited by V.R. Preedy), Academic Press, UK, 129-140.

Zhang, L., Dou, X., Kong, W., Liu, C., Han, X., Yang, M. 2017. Assessment of critical points and development of a practical strategy to extend the applicable scope of immunoaffinity column cleanup for aflatoxin detection in medicinal herbs. Journal of Chromatography A, 1483, 56-63. 